\title{
Årsberetninger
}

\section{De nordiske kriminalistforeninger 2019}

\section{Kriminalistforeningen i Danmark}

Foreningens formand var i 2019 ledende overlæge Dorte Sestoft. Bestyrelsen bestod endvidere af kontorchef Anne-Julie Boesen Pedersen (kasserer og næstformand), advokat Jakob Lund Poulsen, seniorkonsulent Britta Kyvsgaard, departementschef Barbara Bertelsen, professor Thomas Elholm, direktør for Kriminalforsorgen Thorkild Fogde, politidirektør Arne Vedsted Gram, regionsdirektør Anne Marie Heckscher, højesteretsdommer Poul Dahl Jensen, landsdommer og formand for dommerforeningen Mikael Sjöberg samt professor i kriminologi ved Århus universitet Anette Storgaard. Specialkonsulent Susanne Clausen forlod bestyrelsen på eget initiativ i efteråret.

I det forløbne har der været afholdt to bestyrelsesmøde.

Centerchef Ole Hansen fungerede som foreningens interne revisor.

Efter generalforsamlingen i København den 12. februar var der møde med titlen: »Nettets Veje og Vildveje« med oplæg fra ph.d. Simone Molin Friis fra Institut fort Statskundskab på Københavns Universitet samt en repræsentant fra Rigspolitiet, der talte om radikalisering gennem internettet.

Den 20. marts var emnet i København »Unges Kriminalitet på Nettet«. Her fortalte lektor fra Sociologisk Institut på Københavns Universitet, Jakob Demant, samt videnskonsulent Flemming Wridt Jensen og udviklingskonsulent Ninna Lagoni Heide Hansen, Det Kriminalpræventive Råd, og tendenser og muligheder for forebyggelse af online kriminalitet blandt unge.

Den 25. april afholdte foreningen møde i København med emnet »Omrejsende Kriminelle«, hvor lektor Peter Kruize, Det Juridiske Fakultets Forskningscentre på Københavns Universitet, og politiinspektør Mikael Henrik Wern, Nationalt Efterforskningscenter i Glostrup, præsenterde en analyse af, hvordan personer uden fast adresse i Danmarks andel i antallet af sigtelser for - og afgørelser om straffelovskriminalitet har udviklet sig siden årtusindeskiftet, og hvordan denne udvikling kan fortolkes, samt hvorledes Dansk Politis indsats mod kriminalitetsområder er forankret.

Efterårets program begyndte med gå-hjem-mødet den 3. oktober i København havde overskriften »Psykisk Vold«. Her præsenterede vicestatsadvokat, Gyrithe Ulrich, de juridiske og strafferetlige perspektiver i forhold til den nye lovgivning, 
men direktør for Danner, Lisbeth Jessen, diskuterede, hvad denne kriminalisering betyder for voldsramte, samt hvordan man har arbejdet med emnet fra en NGOvinkel.

Den 23. oktober blev der atter i København afholdt møde om »Ungdomskriminalitetsncevnet - Forebyggelse af kriminalitet blandt 10 til 17-årige", hvor sekretariatschef Marianne Schmidt gav et indblik i sagernes behandling, mens Nævnsmedlemmerne Pernille Bird, leder af ungeteamet i Fredensborg Kommune, og Bjørn Poulsen, politikommissær i Nordsjællands Politi, delte deres erfaringer fra nævnets første tid.

Årets sidste gå-hjem-møde blev afholdt den 28. november i København, hvor overlæge på Justitsministeriet, Retspsykiatrisk Klinik, og forfatter af rapporten »Er der en sammenhoeng mellem behandling/støtte af psykisk syge og kriminalitet? - En analyse med henblik på forebyggende tiltag", der udkom i maj 2019, Gitte Ahle, gennemgik rapportens resultater, mens Anders Meinert Pedersen, lægefaglig direktør i Psykiatrien i Region Syddanmark, fortalte om det videre arbejde med de udarbejdede anbefalinger.

Lokalafdelingen i Århus har afholdt et møde den 23. maj om »Unges Kriminalitet på Internettet«, hvor lektor i Sociologi ved Københavns Universitet Jakob Demant genbesøgte Balvigs tese om de lovlydige ungede og svare på, hvordan det ser ud nu, mens lektor i Strafferet og Straffeproces ved Aarhus Universitet Nicolaj Holst beskrev de strafferetlige og socialretlige aspekter af børns og unges deling af seksualiserende billeder og film på nettet.

Lokalafdelingen på Fyn har afholdt to gå-hjem-møder. Den 3. april afholdt foreningen møde i Odense om »Fra integrationspolitik til Hjemsendelsespolitik«, hvor lektor Peter Starup, Syddansk universitet tog udgangspunkt i de seneste års politiske og retsvidenskabelige debat til at belyse fronterne i dansk udlændingeret og forhenværende fængselsinspektør Bodil Philip rejste spørgsmålet om forholdene på udrejsecentret Kærshovedgård er i strid med menneskerettighedskonventionens art. 3 og 5 om forbud mod nedværdigende behandling og retten til frihed.

Den 4. september var der møde med emnet: »Et Viktimologisk Blik på Voldtoegtssagen i Retssystemet« den 4. september, hvor Tine Søberg Specialkonsulent ved Nationalt Forebyggelsescenter Rigspolitiet, Michael Lind, efterforsker ved Sydøstjyllands Politi og Gyrithe Trautner Ulrich vicestatsadvokat ved Statsadvokaten i København fortalte om voldtægtssagens særlige karakter og udfordringer i retssystemet.

Formandskabet og redaktøren af Nordisk Tidsskrift for Kriminalvidenskab har $\mathrm{i}$ årets løb drøftet tidsskriftets fremtid, og det er besluttet, at tidsskriftet senest 1 . januar 2021 overgår til elektronisk udgivelse. 
Ved årets udgang havde Dansk Kriminalistforening et æresmedlem og 254 betalende medlemmer, hvoraf de 5 var kollektive medlemskaber for mindre arbejdspladser (op til 20 medarbejdere) og 10 kollektive medlemskaber for større arbejdspladser. På trods af at foreningen fik 43 nye medlemmer, er det en nedgang på to medlemmer siden 2018 .

Se mere på www.kriminalistforeningen.dk eller på www.facebook.com/ kriminalistforeningen/

Sekretær Laura Arendt, e-mail: sekretariat@kriminalistforeningen.dk

\section{Dorte Sestoft}

Formand

\section{Suomen Kriminalistiyhdistys - Kriminalistföreningen i Finland}

Föreningens styrelse har under redogörelseåret haft följande sammansättning: planerare Petri Danielsson, ordförande; universitetslektor Dan Helenius, viceordförande; advokat Mervi Salo, sekreterare; och doktorand Karoliina Suonpää, kassör. Styrelsens övriga medlemmar bestod av följande personer: specialsakkunnig Anni Karnaranta, rättspsykiater Mika Rautanen och häradsåklagare Yrjö Reenilä. Styrelsens suppleanter bestod av följande personer: doktorand Kristiina Koivukari, överinspektör Leena Mäkipää och direktör Mikko Virkamäki.

Föreningens årsmöte hölls i Vetenskapernas hus den 29 maj 2019. I samband med årsmötet ordnades ett diskussionstillfälle om temat »Cyberkriminalitet som en form av brottslighet - strukturen av brottslighet och de nya utmaningarna för brottsförebyggande«. Vid tillfället hölls presentationer av universitetslektor Matti Näsi vid Helsingfors universitet, häradsåklagare Harri Tiesmaa vid åklagarämbetet i Helsingfors och kriminalöverkommissarien Tero Muurman vid Centralkriminalpolisens Central för bekämpning av cyberbrott. Vid tillfället deltog ca 20 personer.

Vid årets slut hade föreningen 130 medlemmar.

Kriminalistforeningen i Island - Sakfrceðifélag Íslands

Foreningens formand er professor Ragnheiður Bragadóttir.

I 2019 var der intet møde i foreningen. 


\section{Den Norske Kriminalistforening}

I løpet av 2019 har foreningen arrangert ett åpent debattmøte på Det juridiske fakultet, Universitetet i Oslo. Tittelen for debattmøtet, som ble avholdt 4. desember rett etter foreningens årsmøte, var «NAV-skandalen: Hva gikk galt? Hvem har skylda? Hva må gjøres?». Professor Christoffer C. Eriksen, professor Benedikte Moltumyr Høgberg og førsteamanuensis Anders Løvlie satt i panelet, og debatten ble ledet av Runar Torgersen, førstestatsadvokat og styreleder i Kriminalistforeningen.

Foreningens styre har i 2019 bestått av følgende medlemmer: førstestatsadvokat Runar Torgersen, Riksadvokatembetet (leder); advokat Bendik FalchKoslung, Advokatfirmaet Larsen \& Co (nestleder); professor Jørn R.T. Jacobsen, Juridisk fakultet, Universitetet i Bergen (styremedlem); førsteamanuensis Synnøve Ugelvik, Institutt for offentlig rett, Det juridiske fakultet, Universitetet i Oslo; Lucy Furuholmen, advokatfullmektig ved Regjeringsadvokatembetet; forsker Jane Dullum, Institutt for kriminologi og rettssosiologi, Universitetet i Oslo (varamedlem); seniorkonsulent Per Jørgen Ystehede, Institutt for kriminologi og rettssosiologi, Universitetet i Oslo (varamedlem).

Foreningens revisor og sekretær har henholdsvis vært advokat Roar Østby og stipendiat Nils Gunnar Skretting, Institutt for offentlig rett, Det juridiske fakultet, Universitetet i Oslo.

Per dags dato har foreningen ca. 160 medlemmer.

\section{Svenska Kriminalistföreningens årsberättelse 2019}

Vid Svenska Kriminalistföreningens årsmöte den 13 maj 2019 omvaldes vice riksåklagaren Kerstin Skarp till ordförande i föreningen. Till styrelseledamöter omvaldes lagmannen Gudrun Antemar, justitierådet Agneta Bäcklund, kanslirådet Emma Ekström, advokaten Johan Eriksson, biträdande säkerhetspolischefen Charlotte von Essen, forsknings- och utredningsrådet vid Brottsförebyggande rådet Erik Grevholm, utvecklingschefen vid Polismyndigheten Anders Hall, anstalts- och häktesdirektören Hanna Jarl, professorn Jerzy Sarnecki, jur.dr. Erik Svensson och riksmarskalken Fredrik Wersäll.

Till revisor omvaldes departementsrådet Mattias Larsson och hovrättsrådet Christer Lundh. Till revisorssuppleant omvaldes förbundsjuristen Anna Kers.

Styrelsen har under året haft fyra protokollförda sammanträden.

Under året har föreningen arrangerat tre föreningsmöten och en pubkväll.

Årets första möte handlade om skjutvapenvåld. Vid mötet berättade utredarna vid Brottsförebyggande rådet Elin Jönsson och Erik Nilsson om resultaten från en 
intervjustudie med personer som själva varit aktiva i kriminella miljöer där det skjuts.

Vid årsmötet fördes en diskussion om rättsfall som nationellt trauma. Vid mötet deltog tre personer med erfarenhet av att arbeta med uppmärksammade rättsfall - hovrättslagmannen Ragnar Palmkvist, advokaten Johan Eriksson och journalisten och författaren Joakim Palmkvist. Diskussionen handlade om hur man som yrkesperson hanterar rättsfall där inte bara de berörda personerna utan även allmänheten i övrigt har starka känslor och många åsikter. Samtalet leddes av riksmarskalken och f.d. hovrättspresidenten Fredrik Wersäll.

Höstpuben ägnades åt den försöksverksamhet med ett snabbförfarande $\mathrm{i}$ brottmål som sedan början av 2018 bedrivs i norra Stockholm. Chefen för polisområde Stockholm nord Patrick Ungsäter, tillsynschefen vid Åklagarmyndigheten Eva Thunegard och lagmannen Lena Egelin berättade om sina erfarenheter av verksamheten.

Vid höstmötet diskuterades det första året med den nya sexualbrottslagstiftningen, $i$ vilken det tydligare slagits fast att gränsen för straffbar gärning ska gå vid om deltagandet $\mathrm{i}$ en sexuell aktivitet är frivilligt eller inte. I diskussionen medverkade forskningsrådet och docenten Stina Holmberg, kammaråklagaren Christina Voigt samt advokaten Ulrika Borg. Samtalet leddes av justitierådet Petter Asp.

Vid årets utgång hade föreningen cirka 300 medlemmar. 